\title{
Application of fish scale derivatives in ameliorating the phytotoxicity effects of multi-metal contaminated soil on paddy rice
}

sahar maleki-Roudposhti ( $\nabla$ sahar.maleki.r73@gmail.com )

Shiraz University

Reza Ghasemi-Fasaei

Shiraz University

Abdolmajid Ronaghi

Shiraz University

Majid Baghernejad

Shiraz University School of Agriculture

\section{Research Article}

Keywords: fish scale powder, chitin, chitosan, heavy metals, immobilization

Posted Date: January 21st, 2022

DOI: https://doi.org/10.21203/rs.3.rs-1165015/v1

License: (a) (i) This work is licensed under a Creative Commons Attribution 4.0 International License. Read Full License 


\section{Abstract}

Immobilization is an efficient method in the remediation of heavy metal-polluted soils. A greenhouse experiment is conducted to investigate the influence of fish scale powder, chitin, and chitosan on the growth and chemical composition of rice grown on a soil contaminated with $\mathrm{Zn}, \mathrm{Pb}, \mathrm{Cd}$, and Ni. Results showed that the application of fish scale powder, chitin, and chitosan significantly increased root and shoot dry matter yield of rice, but decreased $\mathrm{Pb}$ phytoextraction efficiency. Further, the translocation factor of Ni decreased following the application of fish scale powder and chitosan. Application of fish scale powder decreased $\mathrm{Ni}, \mathrm{Cd}, \mathrm{Zn}$, and $\mathrm{Pb}$ bioavailability in soil. The addition of chitosan reduced $\mathrm{Ni}$ and $\mathrm{Pb}$ concentration in rice shoots. Among different amendments, only the application of chitosan had a significant effect on the reduction of $\mathrm{Zn}$ content in rice root. Considering that the translocation factors were less than one in all treatments, it can be concluded that biostabilization of the studied metals has occurred. based on the obtained results fish scale derivatives including fish scale powder and chitosan play an important role in the removal of heavy metals due to having suitable functional groups.

Therefore, it can be deduced that due to the economic feasibility, environmentally friendly, and high metal removal capability of chitosan and fish scale powder, these two amendments are highly recommendable to be applied in multi-metal polluted soils for increasing metals removal and hence decreasing their phytotoxicity.

\section{Introduction}

Hazardous heavy metals (HMs) pollution from anthropogenic sources and natural inputs is a major threat to human health (Kamari et al. 2011; Liphadzi and Kirkham 2006). Accumulation of HMs in agricultural soils is a serious and increasing problem because of rapidly growing industrial areas, and excessive use of chemical fertilizers and sewage wastes ( $\mathrm{Li}$ et al. 2005; Wong et al. 2002; Zeng et al. 2008; Zhao et al. 2010). Increasing HMs in agricultural soils can result in a decrease in soil fertility, crop yield losses, and the entrance of HMs to the food web through plants, causing serious implications for animal and human health (Cui et al. 2018; Kang et al. 2016; Lahori et al. 2017; Xiong et al. 2016; Zibaei et al. 2020). It has been shown that long-term exposure of human beings to some $\mathrm{HMs}$ such as $\mathrm{Cd}$, and $\mathrm{Pb}$ increase the risk of mortality from cancer (Fan et al. 2017; Wang et al. 2011). While previously most researchers studied soils polluted with a single $\mathrm{HM}$, recently, more attention has been paid to the multimetal polluted soils (Razmi et al. 2021; Su 2014).

Rice is a significant dietary source that is consumed by more than half of the world's population (Fao 2012; Rabbani et al. 2015). This plant may assimilate a substantial amount of HMs from polluted soil due to its high biomass and exponential growth(Arao et al. 2010; Guo et al. 2020). The consumption of rice contaminated with $\mathrm{HMs}$ can lead not only to mental health disorders but to many debilitating diseases(Guo et al. 2020). Hence, the accumulation and transference of HMs into a soil-rice system have become a mounting concern (Zhao et al. 2010). 
The mobility and bioavailability of heavy and trace metals in the environment are affected by adsorption and desorption in soils (Martınez-Villegas et al. 2004; Mayel et al. 2014). Diverse soil properties such as $\mathrm{pH}$, organic matter content, cation exchange capacity (CEC), oxidation-reduction status (Eh), the contents of clay minerals, and calcium carbonate are closely related to the adsorption-desorption process(Antoniadis et al. 2008; Kashem and Singh 2001; Zeng et al. 2011). It appears that among different soil properties, soil pH plays the most important role in controlling HMs bioavailability (Zeng et al. 2008). The mobility and bioavailability of most HMs increase with decreasing soil pH (Badawy et al. 2002; Du Laing et al. 2009; Wang et al. 2006). Flooding of paddy soils causes changes in the values of soil $\mathrm{pH}$, as well as redox potential and makes the paddy field a complex system. Such changes in soil properties may influence the negative charges of soil that are important in the adsorption of metals and hence their solubility (Hussain et al. 2021; Li et al. 2014). The content of $\mathrm{CaCO}_{3}$ considerably impacted the activities of HMs in soil and their absorption by the plant (Wang et al. 2020; XIAN et al. 1988).

When HMs contamination of soil exceeds a certain threshold, soil loses its natural capacity to control the availability of metal ions consequently soil degradation occurs. Therefore, soil remediation technologies are required under such circumstances (Raicevic et al. 2005; Shi et al. 2009; Sunarso and Ismadji 2009). Various soil remediation techniques have been employed to reduce the risks associated with HMs efflux into soil, including soil removal and replacement, soil washing, phytoremediation, and in-situ immobilization(Bolan et al. 2014; Yin et al. 2015). From the view of being fast and economical, in situ immobilization is a well-known method. This method reduces the availability of metal ions through sorption, complexation, and precipitation using organic/inorganic amendments(Chauhan et al. 2012; Tripathi et al. 2018; Yin et al. 2015).

One of the fundamental aspects of the fishing industry in Iran is the presence of different seas and rivers in different parts of this country (Ghobadian 2012). The by-products of fish processing are considerable quantities that usually include unwanted parts such as shellfish, unused and underused items (Wasswa et al. 2007). Immense quantities of waste materials that remain in the environment create pollution and health problems. Hence, the recovery of value-added products from these residues constitutes an important waste reduction strategy (Kongsri et al. 2013; Pal and Maiti 2020). Among the polysaccharide in the marine environment, chitin (CTN) has attracted much attention as the second most available natural polymer after cellulose (Muxika et al. 2017; Silva et al. 2012). It can be converted into chitosan (CTS) through deacetylation (Ghasemi-Fasaei et al. 2021; Muxika et al. 2017). Functional groups are particularly effective in immobilizing metals due to their ability to bind or complex them. The presence of numerous amino and hydroxyl groups in CTS illustrates a high adsorption potential for HMs (Chu 2002; Dhakal et al. 2005; Tripathi et al. 2017). The molecule of CTS consists of amino and hydroxyl groups that can act as binding sites for metal ion complexation. It is a powerful chelating agent and possesses high adsorption capacity for a variety of $\mathrm{HMs}$ including $\mathrm{Zn}, \mathrm{Cu}$, and $\mathrm{Hg}$. In addition, the absence of poisoning effects along with its fast decomposition makes CTS appropriate to be used in various environments (Uthairatanakij et al. 2007). 
This study aims to investigate the impact of fish scales powder (FSP), CTN, and CTS on the amelioration of $\mathrm{HMs}$ phytotoxicity in rice grown on a soil contaminated with $\mathrm{Zn}, \mathrm{Ni}, \mathrm{Cd}$, and $\mathrm{Pb}$. To the best of our knowledge, this is the first study of the impact of fish scales and its derivatives on multi-metal contaminated soil on paddy rice.

\section{Materials And Methods}

\section{Soil collection and analysis}

Sufficient soil samples to prepare a composite sample were collected from the surface horizon $(0-30$ $\mathrm{cm}$ ) of Bajgah Agricultural Experiment Station, Shiraz University, Shiraz, Iran, in the southern Iran $\left(29^{\circ} 35^{\prime}\right.$ $\left.\mathrm{N}, 52^{\circ} 35^{\prime} \mathrm{E}\right)$. Some properties of the composite sample were determined using standard methods. The amounts of sand, silt, and clay were 30,34 , and $36 \%$, respectively. The values of electrical conductivity (EC) and cation exchange capacity (CEC) were $0.13 \mathrm{dS} \mathrm{m}^{-1}$, and $26 \mathrm{cmol}_{(+)} \mathrm{kg}^{-1}$, respectively. The $\mathrm{pH}$ value in saturated paste was 7.7.

\section{Preparation of amendments}

Mahisefid, Rutilus frisii kutum, is a cyprinid fish which is an important economic species in the Caspian Sea (Abdolhay et al. 2010). The fish scales of mahisefid (Caspian kutum) collected from local markets in Anzali port, Gilan provience, Iran. Fish scales were separated from fish waste, washed with distilled water and sun-dried for two days. The sun-dried materials were oven dried and powdered to make FSP to be used as an amendment and as raw material for the preparation of other amendments of CTN and CTS (Ghasemi-Fasaei et al. 2021).

\section{Treatments and experimental design}

Soil samples were contaminated with $125 \mathrm{mg} \cdot \mathrm{kg}^{-1}$ of each $\mathrm{Cd}, \mathrm{Zn}, \mathrm{Pb}$, and $\mathrm{Ni}$ as nitrate sources and incubated for one month at $25 \pm 2^{\circ} \mathrm{C}$ under saturated moisture. The experiment was carried out in a completely randomized design with 4 amendments (control, $0.5 \% \mathrm{FSP}, 0.5 \% \mathrm{CTN}$, and $0.5 \% \mathrm{CTS}$ ). After incubation, the contaminated soils were transferred to $2 \mathrm{~kg}$ pots and six rice seeds were sown in each pot and thinned to three uniform stands one week after emergence.

\section{Plant harvest and tissue analyses}

The rice was harvested after 7 weeks of growth, and then shoots and roots were separated from soil. Both parts were washed carefully, oven-dried, weighted, and powdered. Following the method described by (Yingang et al. 2018), each sample (one gram of plant material) was digested in a mixture of hydrochloric acid and nitric acid with a ratio of $(1: 3)$ at $180^{\circ} \mathrm{C}$ for one hour. Then, two $\mathrm{mL}$ of $30 \% \mathrm{H}_{2} \mathrm{O}_{2}$ were added. This procedure was repeated one more time to make sure that the digestion process was completed. The sample was next diluted to the final volume of $50 \mathrm{~mL}$ with nitric acid. The concentrations of $\mathrm{Zn}, \mathrm{Pb}, \mathrm{Ni}$, and $\mathrm{Cd}$ were determined using an atomic absorption spectrophotometer (Shimadzu AA 670 G, Japan). 


\section{Calculations and statistical analyses}

The values of phytoremediation criteria were calculated using the following equations.

Translocation factor (TF) = metal content in aerial part /metal content in root

Phytoextraction efficiency $(\mathrm{PE})\left(\mu \mathrm{g} \mathrm{g}^{-1}\right)=$ shoot metal uptake/ root dry weight

Uptake efficiency $(\mathrm{UE})\left(\mu \mathrm{g} \mathrm{g}^{-1}\right)=($ shoot metal uptake + root metal uptake)/ root dry weight

Data were statistically analyzed using analysis of variance of a one-way factor of a completely randomized design, and means were compared by the Duncan's Multiple Range Test at $5 \%$ level of significance using SAS software packages ( Ver 9.3).

\section{Results And Discussions}

\section{Root and shoot dry matter yield}

According to the results, the addition of amendments significantly increased the mean root and shoot dry weight of rice as compared to the control (Figure 1). Application of FSP, CTN, and CTS increased shoot dry weight of rice by 255,105 , and $86.6 \%$, and root dry weight of rice by 112,124 , and $72.7 \%$, respectively, as compared to the control. The highest shoot dry weight was observed following the application of FSP to the multi-metal polluted soil (Figure 1). Results of a previous research indicated that FSP treatment considerably improved all morphological characters of Vigna radiata L. in a calcareous soil, probably due to the role of FSP as an organic fertilizer that improves soil properties(Alkhafaji and Elkheralla 2019).

Previous studies have reported that the application of CTS had positive effects on the dry biomass of sunflower (Turan et al. 2018b), lettuce(Turan 2019), and calendula (Heidari et al. 2020). It appears that CTS improves plant growth through the enhancement of the uptake of essential elements that is resulted from its ability to chelate ions (Chatelain et al. 2014; Heidari et al. 2020; Katiyar et al. 2015). In addition, the presence of about $7.8 \%$ nitrogen in CTS, which acts as a nitrogen source for plants can also lead to an increase in plant biomass (Kamari et al. 2011).

The concentrations of $\mathrm{Pb}$ in rice shoot and root are illustrated in Figure 2. According to this figure, FSP was the most effective treatment in reducing $\mathrm{Pb}$ concentrations in rice shoot. The presence of amino, carboxylic, phosphate and carbonyl groups in FSP can lead to the sorption of Pb (Nadeem et al. 2008). (Gilmour et al. 2013), and (Zhang et al. 2010) reported that the utilization of FSP leads to the immobilization of $\mathrm{HMs}$ in polluted sediment. The possible reason behind this phenomenon can be that the precipitation of $\mathrm{Pb}$ hydroxides resulted from the connection of $\mathrm{Pb}^{2+}$ ions with FSP via ionic bonds (Pal and Maiti 2020). 
Compared to control, the application of CTS and FSP treatments caused 50, and $65 \%$ decrease in shoots $\mathrm{Pb}$ concentration, respectively. Also, the application of FSP, CTN, and CTS caused significant decreases in mean root $\mathrm{Pb}$ concentration as compared to control treatment. Positive effects of CTS in decreasing metals uptake by rapeseed has been reported by (Kamari et al. 2012). The addition of CTS as a natural polymer compound that is not degraded easily in alkaline soil leads to an increase in the content of OM and reduced the impacts of $\mathrm{Pb}$ during a two-year experimental period (CHANG et al. 2020). In addition, the presence of organic-Ca, amino, and hydroxyl functional groups in CTS can form stable chelates with $\mathrm{Pb}$, and hence alleviate the harmful effects of $\mathrm{Pb}$ in the soil through decreasing in the contents of bioavailable Pb in soil (Koptsik 2014; Zhang et al. 2011).

According to the data given in figure 3 , the application of FSP and CTS signi $\square$ cantly decreased the contents of $\mathrm{Ni}$ in rice shoots as compared to control. The lowest contents of $\mathrm{Ni}$ in rice shoots are found in plants of FSP treatment. It is likely that the adsorption of $\mathrm{HM}$ ions such as $\mathrm{Ni}^{2+}$ by FSP showed that ion exchange reaction can decrease metal solubility (Shaikhiev et al. 2020; Villanueva-Espinosa et al. 2001). Application of CTS noticeably reduced Ni concentration in rice root. The results of the present study are in agreement with the results obtained from an earlier study (Heidari et al. 2020) which showed that calcareous soil amended with CTS reduced Ni concentration in plants shoots. Also, it has been reported the use of CTS reduced $\mathrm{Ni}$ bioavailability in lettuce through the immobilization of $\mathrm{Ni}$ in contaminated soils (Turan 2019).(Turan et al. 2018a) also reported that CTS significantly decreased the concentrations of $\mathrm{Ni}$ in the brinjal plant. Results indicated that the use of FSP had a significant effect on the metals immobilization due to the involvement of the carbonyl, nitro and amino groups in FSP(Othman et al. 2016). Although CTN has unique properties such as biocompatibility, bioactivity, and biodegradability, its poor solubility is the main factor limiting CTN utility (Muxika et al. 2017). The lower efficiency of CTN in the adsorption of some metal ions can be attributed to its lower functional groups compared to CTS (Camci-Unal and Pohl 2010).

None of the studied amendments had a significant effect on Cd concentration of rice shoot (Figure 4). The absorption of some HMs such as $\mathrm{Cd}$ from soil solution by rice is extensively affected by the redox potential of the soil(Watanabe et al. 1996; Zazoli et al. 2006). During flooding, Cd may be immobilized and precipitates as CdS, while under aerobic conditions, CdS is dissolved and released as $\mathrm{Cd}^{2+}$ (Huang et al. 2013; Sun et al. 2007). Addition of FSP significantly decreased Cd content of rice root in comparison with the control. Although CTN, and CTS reduced the Cd concentration in rice roots, these decreases were not statistically significant. (Pal and Maiti 2020) observed that the use of FSP immobilized HMs in contaminated sediment. It appears that the presence of amide, carbonate, and phosphate functional groups were responsible for $\mathrm{Cd}$ and $\mathrm{Pb}$ ions sorption on FSP biosorbent surface. The polymeric arrangement of FSP biomass is responsible for the presence of negative charges that are derived from the ionization of organic and inorganic functional groups on its surface (Nadeem et al. 2008).

Application of CTS caused a significant decrease in the content of $\mathrm{Zn}$ in the root of plants as compared to the control. However, the use of FSP and CTN had no significant impact on Zn concentration compared to the control (Figure 5). It's likely that organic matter forms a coordination complex with Zn based on 
Lewis's acid-base theory. Hence, this can be acceptable that $\mathrm{Zn}^{2+}$ ions act as the acid and electron pair acceptors which react with CTS that acts as a base (Gerente et al. 2007). The cause of $\mathrm{Zn}$ reduction in plant tissues following CTS application can be attributed to Zn immobilization(Park et al. 2011).

\section{Phytoremediation criteria}

The values of uptake efficiency (UE), phytoextraction efficiency (PE), and translocation factor (TF) are given in Table 1. Results showed that the application of FSP increased the values of UE for Ni and Zn. However, the addition of amendments had no significant effect on the values of UE for $\mathrm{Cd}$, and $\mathrm{Pb}$. The addition of studied amendments significantly decreased $\mathrm{PE}$ of $\mathrm{Pb}$ in rice plant tissue. Following the application of CTS, the TF values of Ni significantly decreased in comparison with the control treatment. The value of TF is the ratio of metal concentration in root to that of shoot (Asilian et al. 2018) and demonstrates the ability of a plant to transfer metals from the roots to the shoots (Kutrowska et al. 2017). In the case of $\mathrm{Ni}$, the TF value decreased with applying FSP, and CTS treatments, whereas CTN had no significant impact on the transport of Ni from the root to shoot of rice (Table 1). It is likely that the high efficacy of CTS for Ni chelating is owing to the existence of a large number of amino and hydroxyl groups in its structure that led to declining Ni phytoavailability in soil and consequently lowering the uptake of this metal by rice. Consistent with our results, it has been reported that soil amendment with CTS immobilized Ni in soil and reduced Ni content in lettuce(Turan 2019). The addition of FSP decreased the mean TF value of $\mathrm{Ni}$ in the rice plant (Table 1). If values of TF is $>1$, then plants has a high potential for metal accumulation in the roots and TF value of greater than 1 , indicates the plant's ability to transfer metals from root to the shoot that this characteristic plays a significant role in the phytoextraction of HMs from polluted soils (Baker and Brooks 1989; Cunningham et al. 1995). Overall, the fact that the values of TF for all studied metals were lower than one, demonstrated that rice maintains most of the metals in its root tissues and phytostabilization is the main mechanism of this plant in confronting high levels of the studied metals (Asilian et al. 2018; Cunningham et al. 1995) 
Table 1

Effect of FSP and its derivaties on the translocation factor, phytoextraction efficiency, and uptake efficiency of metals in rice plant.

\begin{tabular}{|c|c|c|c|c|}
\hline treatment & metal & Translocation factor & Phytoextraction efficiency $\left(\mu \mathrm{g} \mathrm{g}^{-1}\right)$ & $\begin{array}{l}\text { Uptake efficiency } \\
\left(\mu g^{-1}\right)\end{array}$ \\
\hline C & $\mathrm{Ni}$ & $0.44 \mathrm{a}$ & $146.35 \mathrm{a}$ & $141.21 b$ \\
\hline FSP & $\mathrm{Ni}$ & $0.29 \mathrm{~b}$ & $131.51 \mathrm{a}$ & $173.15 \mathrm{a}$ \\
\hline CTN & $\mathrm{Ni}$ & $0.36 a b$ & $94.07 \mathrm{ab}$ & $155.31 \mathrm{ab}$ \\
\hline CTS & $\mathrm{Ni}$ & $0.29 b$ & $70.02 b$ & $108.63 \mathrm{c}$ \\
\hline C & $\mathrm{Zn}$ & $0.32 \mathrm{a}$ & $126.58 \mathrm{a}$ & $167.94 \mathrm{~b}$ \\
\hline FSP & $\mathrm{Zn}$ & $0.30 \mathrm{a}$ & $199.38 \mathrm{a}$ & $283.58 \mathrm{a}$ \\
\hline CTN & $\mathrm{Zn}$ & $0.34 \mathrm{a}$ & $102.77 \mathrm{a}$ & $174.71 \mathrm{~b}$ \\
\hline CTS & $\mathrm{Zn}$ & $0.54 \mathrm{a}$ & $134.01 \mathrm{a}$ & $200.74 b$ \\
\hline C & $\mathrm{Cd}$ & $0.37 a$ & 75.04 a & $125.87 \mathrm{a}$ \\
\hline FSP & $\mathrm{Cd}$ & $0.04 \mathrm{~b}$ & $18.29 \mathrm{c}$ & $117.39 a$ \\
\hline CTN & $\mathrm{Cd}$ & $0.23 \mathrm{a}$ & $44.78 \mathrm{~b}$ & $141.11 \mathrm{a}$ \\
\hline CTS & $\mathrm{Cd}$ & $0.41 \mathrm{a}$ & $92.24 \mathrm{a}$ & $137.27 \mathrm{a}$ \\
\hline C & $\mathrm{Pb}$ & $0.44 \mathrm{a}$ & $235.84 \mathrm{a}$ & 217.27 a \\
\hline FSP & $\mathrm{Pb}$ & $0.38 \mathrm{a}$ & $140.09 b$ & $160.19 \mathrm{a}$ \\
\hline CTN & $\mathrm{Pb}$ & $0.45 \mathrm{a}$ & $127.27 b$ & $153.91 \mathrm{a}$ \\
\hline CTS & $\mathrm{Pb}$ & $0.47 a$ & $140.82 b$ & $153.94 \mathrm{a}$ \\
\hline
\end{tabular}

\section{Conclusion}

Application of fish scale powder and chitosan noticeably reduced the values of $\mathrm{Pb}$, and $\mathrm{Ni}$ concentration in the root and aerial parts of rice grown on the heavy-metal polluted soils. Chitosan amendment effectively decreased root $\mathrm{Zn}$ concentration, probably due to the abundance of reactive functional groups in this biosorbent amendment. Maximum accumulation of metals in rice root tissues suggested the weakness of this plant in translocating metals from root to shoot and the presence of phytostabilization as the main remediation mechanism. Fish scale derivatives play significant roles in the removal of metals by complexing metals ions in contaminated soils. Hence, the utilization of fish scale derivatives especially CTS and FSP not only can reduce substantial amounts of solid wastes but also is an 
economical and efficient technique in decreasing HMs phytotoxicity through the bioadsorption of these metals in polluted soils.

\section{Declarations}

1. Ethical Approval: Not applicable.

2. Consent to Participate: Not applicable.

3. Consent to Publish: Not applicable.

\section{Authors Contributions:}

- Sahar Maleki-Roudposhti: Software, Data curation, Investigation, Resources, and Writing- review \& editing.

- Reza Ghasemi-Fasaei: Supervision, Project administration, Formal analysis, and Writing - original draft.

- Abdolmajid Ronaghi: Supervision, Project administration.

- Majid Baghernejad: Supervision, Project administration.

5. Funding: This work was financially supported by Shiraz University, Shiraz, Iran.

6. Competing Interests: The authors declare that they have no competing interests.

7. Availability of data and materials: All data generated or analysed during this study are included in this published article (and its supplementary information files).

\section{References}

Abdolhay H, Pourkazemi M, Rezvani S, Kamal Abdul Satar M, Hosseinzadeh Sahafi H, Siti Khalijah D, Siti Shapor S (2010) Morphometrics studies of Mahisefid (Rutilus frisii kutum, Kamensky, 1901) from selected rivers in the southern Caspian Sea

Alkhafaji BY, Elkheralla RJ (2019) EFFECT OF ADDING FISH SCALES IN AGRICULTURAL SOILS AND SOME CHARACTERISTICS OF VIGNA RADIATA L Plant Archives 19:1041-1043

Antoniadis V, Robinson J, Alloway B (2008) Effects of short-term pH fluctuations on cadmium, nickel, lead, and zinc availability to ryegrass in a sewage sludge-amended field Chemosphere 71:759-764

Arao T, Ishikawa S, Murakami M, Abe K, Maejima Y, Makino T (2010) Heavy metal contamination of agricultural soil and countermeasures in Japan Paddy and water Environment 8:247-257

Asilian E, Ghasemi-Fasaei R, Ronaghi A, Sepehri M, Niazi A (2018) Effects of microbial inoculations and surfactant levels on biologically-and chemically-assisted phytoremediation of lead-contaminated soil by 
maize (Zea Mays L.) Chemistry and Ecology 34:964-977

Badawy S, Helal M, Chaudri A, Lawlor K, McGrath S (2002) Soil Solid-Phase Controls Lead Activity in Soil Solution Journal of Environmental Quality 31:162-167

Baker AJ, Brooks R (1989) Terrestrial higher plants which hyperaccumulate metallic elements. A review of their distribution, ecology and phytochemistry Biorecovery 1:81-126

Bolan N et al. (2014) Remediation of heavy metal (loid) s contaminated soils-to mobilize or to immobilize? Journal of hazardous materials 266:141-166

Camci-Unal G, Pohl NL (2010) Quantitative determination of heavy metal contaminant complexation by the carbohydrate polymer chitin Journal of Chemical \& Engineering Data 55:1117-1121

CHANG H-q, WANG Q-z, LI Z-j, Jie W, XU X-f, SHI Z-y (2020) The effects of calcium combined with chitosan amendment on the bioavailability of exogenous $\mathrm{Pb}$ in calcareous soil Journal of Integrative Agriculture 19:1375-1386

Chatelain PG, Pintado ME, Vasconcelos MW (2014) Evaluation of chitooligosaccharide application on mineral accumulation and plant growth in Phaseolus vulgaris Plant Science 215:134-140

Chauhan D, Jaiswal M, Sankararamakrishnan N (2012) Removal of cadmium and hexavalent chromium from electroplating waste water using thiocarbamoyl chitosan Carbohydrate Polymers 88:670-675

Chu K (2002) Removal of copper from aqueous solution by chitosan in prawn shell: adsorption equilibrium and kinetics Journal of Hazardous Materials 90:77-95

Cui M, Lee Y, Choi J, Kim J, Han Z, Son Y, Khim J (2018) Evaluation of stabilizing materials for immobilization of toxic heavy metals in contaminated agricultural soils in China Journal of Cleaner Production 193:748-758

Cunningham SD, Berti WR, Huang JW (1995) Phytoremediation of contaminated soils Trends in biotechnology 13:393-397

Dhakal RP, Ghimire KN, Inoue K (2005) Adsorptive separation of heavy metals from an aquatic environment using orange waste Hydrometallurgy 79:182-190

Du Laing G, Rinklebe J, Vandecasteele B, Meers E, Tack FM (2009) Trace metal behaviour in estuarine and riverine floodplain soils and sediments: a review Science of the total environment 407:3972-3985

Fan Y, Zhu T, Li M, He J, Huang R (2017) Heavy metal contamination in soil and brown rice and human health risk assessment near three mining areas in central China Journal of healthcare engineering 2017 Fao F (2012) agriculture organization of the United Nations. 2012 FAO statistical yearbook 
Gerente C, Lee V, Cloirec PL, McKay G (2007) Application of chitosan for the removal of metals from wastewaters by adsorption-mechanisms and models review Critical reviews in environmental science and technology 37:41-127

Ghasemi-Fasaei R, Paridar Z, Ronaghi A (2021) The role of low molecular weight organic acids in release kinetics of zinc and cadmium in polluted calcareous soil in the presence of fish scales derivatives Chemistry and Ecology 37:50-63

Ghobadian B (2012) Liquid biofuels potential and outlook in Iran Renewable and Sustainable Energy Reviews 16:4379-4384

Gilmour CC et al. (2013) Activated carbon mitigates mercury and methylmercury bioavailability in contaminated sediments Environmental science \& technology 47:13001-13010

Guo B et al. (2020) Health risk assessment of heavy metal pollution in a soil-rice system: a case study in the Jin-Qu Basin of China Scientific reports 10:1-11

Heidari J, Amooaghaie R, Kiani S (2020) Impact of chitosan on nickel bioavailability in soil, the accumulation and tolerance of nickel in Calendula tripterocarpa International journal of phytoremediation 22:1175-1184

Huang J-H, Wang S-L, Lin J-H, Chen Y-M, Wang M-K (2013) Dynamics of cadmium concentration in contaminated rice paddy soils with submerging time Paddy and Water Environment 11:483-491

Hussain B, Ashraf MN, Abbas A, Li J, Farooq M (2021) Cadmium stress in paddy fields: effects of soil conditions and remediation strategies Science of The Total Environment 754:142188

Kamari A, Pulford I, Hargreaves J (2011) Binding of heavy metal contaminants onto chitosans-an evaluation for remediation of metal contaminated soil and water Journal of environmental management 92:2675-2682

Kamari A, Pulford I, Hargreaves J (2012) Metal accumulation in Lolium perenne and Brassica napus as affected by application of chitosans International journal of phytoremediation 14:894-907

Kang C-H, Kwon Y-J, So J-S (2016) Bioremediation of heavy metals by using bacterial mixtures Ecological Engineering 89:64-69

Kashem M, Singh B (2001) Metal availability in contaminated soils: I. Effects of floodingand organic matter on changes in Eh, pH and solubility of $\mathrm{Cd}$, Ni andZn Nutrient Cycling in Agroecosystems 61:247255

Katiyar D, Hemantaranjan A, Singh B (2015) Chitosan as a promising natural compound to enhance potential physiological responses in plant: a review Indian Journal of Plant Physiology 20:1-9 
Kongsri S, Janpradit K, Buapa K, Techawongstien S, Chanthai S (2013) Nanocrystalline hydroxyapatite from fish scale waste: Preparation, characterization and application for selenium adsorption in aqueous solution Chemical engineering journal 215:522-532

Koptsik G (2014) Modern approaches to remediation of heavy metal polluted soils: A review Eurasian Soil Science 47:707-722

Kutrowska A et al. (2017) Effects of binary metal combinations on zinc, copper, cadmium and lead uptake and distribution in Brassica juncea Journal of Trace Elements in Medicine and Biology 44:32-39

Lahori AH et al. (2017) Potential use of lime combined with additives on (im) mobilization and phytoavailability of heavy metals from $\mathrm{Pb} / \mathrm{Zn}$ smelter contaminated soils Ecotoxicology and environmental safety $145: 313-323$

Li W, Xu B, Song Q, Liu X, Xu J, Brookes PC (2014) The identification of 'hotspots' of heavy metal pollution in soil-rice systems at a regional scale in eastern China Science of the Total Environment 472:407-420

Li Z, Li L, Chen GPJ (2005) Bioavailability of Cd in a soil-rice system in China: soil type versus genotype effects Plant and soil 271:165-173

Liphadzi M, Kirkham M (2006) Availability and plant uptake of heavy metals in EDTA-assisted phytoremediation of soil and composted biosolids South African Journal of Botany 72:391-397

Martınez-Villegas N, Flores-Vélez LM, Domınguez O (2004) Sorption of lead in soil as a function of pH: a study case in México Chemosphere 57:1537-1542

Mayel S, Ghasemi-Fasaei R, Karimian N, Ronaghi A, Zarei M, Jarrah M (2014) Desorption behaviour of lead in two calcareous soils as affected by $\mathrm{Pb}$ level without and with compost supply Archives of Agronomy and Soil Science 60:265-274

Muxika A, Etxabide A, Uranga J, Guerrero P, De La Caba K (2017) Chitosan as a bioactive polymer: Processing, properties and applications International Journal of Biological Macromolecules 105:13581368

Nadeem R, Ansari TM, Khalid AM (2008) Fourier transform infrared spectroscopic characterization and optimization of $\mathrm{Pb}$ (II) biosorption by fish (Labeo rohita) scales Journal of Hazardous Materials 156:6473

Othman N, Abd-Kadir A, Zayadi N (2016) Waste fish scale as cost effective adsorbent in removing zinc and ferum ion in wastewater J Eng Appl Sci 11:1584-1592

Pal D, Maiti SK (2020) An approach to counter sediment toxicity by immobilization of heavy metals using waste fish scale derived biosorbent Ecotoxicology and environmental safety 187:109833 
Park JH, Choppala GK, Bolan NS, Chung JW, Chuasavathi T (2011) Biochar reduces the bioavailability and phytotoxicity of heavy metals Plant and soil 348:439-451

Rabbani D, Dehghani R, Gilasi H, Abadi H (2015) Evaluation of heavy metals in Iranian and Non-Iranian rice supplied by shopping centers of Kashan, Iran International archives of health sciences 2:25-29

Raicevic S, Kaludjerovic-Radoicic T, Zouboulis A (2005) In situ stabilization of toxic metals in polluted soils using phosphates: theoretical prediction and experimental verification Journal of Hazardous Materials 117:41-53

Razmi B, Ghasemi-Fasaei R, Ronaghi A, Mostowfizadeh-Ghalamfarsa R (2021) Investigation of factors affecting phytoremediation of multi-elements polluted calcareous soil using Taguchi optimization Ecotoxicology and Environmental Safety 207:111315

Shaikhiev IG, Kraysman NV, Sverguzova SV, Spesivtseva SE, Yarothckina AN (2020) Fish scales as a biosorbent of pollutants from wastewaters and natural waters (A literature review) Biointerface Research in Applied Chemistry 10:6893-6905

Shi W-y, Shao H-b, Li H, Shao M-a, Du S (2009) Progress in the remediation of hazardous heavy metalpolluted soils by natural zeolite Journal of Hazardous Materials 170:1-6

Silva TH et al. (2012) Materials of marine origin: a review on polymers and ceramics of biomedical interest International Materials Reviews 57:276-306

Su C (2014) A review on heavy metal contamination in the soil worldwide: Situation, impact and remediation techniques Environmental Skeptics and Critics 3:24

Sun L, Chen S, Chao L, Sun T (2007) Effects of flooding on changes in Eh, pH and speciation of cadmium and lead in contaminated soil Bulletin of Environmental Contamination and Toxicology 79:514-518

Sunarso J, Ismadji S (2009) Decontamination of hazardous substances from solid matrices and liquids using supercritical fluids extraction: a review Journal of hazardous materials 161:1-20

Tripathi N, Choppala G, Singh RS (2017) Evaluation of modified chitosan for remediation of zinc contaminated soils Journal of Geochemical Exploration 182:180-184

Tripathi N, Choppala G, Singh RS, Hills CD (2018) Impact of modified chitosan on pore water bioavailability of zinc in contaminated soils Journal of Geochemical Exploration 186:94-99

Turan V (2019) Confident performance of chitosan and pistachio shell biochar on reducing $\mathrm{Ni}$ bioavailability in soil and plant plus improved the soil enzymatic activities, antioxidant defense system and nutritional quality of lettuce Ecotoxicology and environmental safety 183:109594 
Turan V, Khan SA, Iqbal M, Ramzani PMA, Fatima M (2018a) Promoting the productivity and quality of brinjal aligned with heavy metals immobilization in a wastewater irrigated heavy metal polluted soil with biochar and chitosan Ecotoxicology and environmental safety 161:409-419

Turan V, Ramzani PMA, Ali Q, Abbas F, Iqbal M, Irum A, Khan W-u-D (2018b) Alleviation of nickel toxicity and an improvement in zinc bioavailability in sunflower seed with chitosan and biochar application in $\mathrm{pH}$ adjusted nickel contaminated soil Archives of Agronomy and Soil Science 64:1053-1067

Uthairatanakij A, Teixeira da Silva J, Obsuwan K (2007) Chitosan for improving orchid production and quality Orchid Science and Biotechnology 1:1-5

Villanueva-Espinosa J, Hernandez-Esparza M, Ruiz-Trevino F (2001) Adsorptive properties of fish scales of Oreochromis Niloticus (Mojarra Tilapia) for metallic ion removal from waste water Industrial \& engineering chemistry research 40:3563-3569

Wang AS, Angle JS, Chaney RL, Delorme TA, Reeves RD (2006) Soil pH effects on uptake of Cd and Zn by Thlaspi caerulescens Plant and soil 281:325-337

Wang J, Wang K, Guo Y, Niu J (2020) Photochemical degradation of nebivolol in different natural organic matter solutions under simulated sunlight irradiation: Kinetics, mechanism and degradation pathway Water Research 173:115524

Wang M, Xu Y, Pan S, Zhang J, Zhong A, Song H, Ling W (2011) Long-term heavy metal pollution and mortality in a Chinese population: an ecologic study Biological trace element research 142:362-379

Wasswa J, Tang J, Gu X (2007) Utilization of fish processing by-products in the gelatin industry Food Reviews International 23:159-174

Watanabe T, Shimbo S, Moon C-S, Zhang Z-W, Ikeda M (1996) Cadmium contents in rice samples from various areas in the world Science of the total environment 184:191-196

Wong S, Li X, Zhang G, Qi S, Min Y (2002) Heavy metals in agricultural soils of the Pearl River Delta, South China Environmental pollution 119:33-44

XIAN X, HOMMA S, KUNO K (1988) Relationship between concentration of heavy metals in soil and contents of that absorbed by mulberry plant The Journal of Sericultural Science of Japan 57:481-488

Xiong T et al. (2016) Measurement of metal bioaccessibility in vegetables to improve human exposure assessments: field study of soil-plant-atmosphere transfers in urban areas, South China Environmental geochemistry and health 38:1283-1301

Yin Z, Cao J, Li Z, Qiu D (2015) Reducing the bioavailability of cadmium in contaminated soil by dithiocarbamate chitosan as a new remediation Environmental Science and Pollution Research 22:96689675 
Yingang L et al. (2018) Effect of silicon on growth, physiology, and cadmium translocation of tobacco (Nicotiana tabacum L.) in cadmium-contaminated soil Pedosphere 28:680-689

Zazoli MA, Bazerafshan E, Hazrati A, Tavakkoli A (2006) Determination and estimation of cadmium intake from Tarom rice Journal of Applied Sciences and Environmental Management 10:147-150

Zeng F, Ali S, Zhang H, Ouyang Y, Qiu B, Wu F, Zhang G (2011) The influence of pH and organic matter content in paddy soil on heavy metal availability and their uptake by rice plants Environmental pollution 159:84-91

Zeng F, Mao Y, Cheng W, Wu F, Zhang G (2008) Genotypic and environmental variation in chromium, cadmium and lead concentrations in rice Environmental pollution 153:309-314

Zhang J, Li R, Zhang Y, Pan Q (2011) Composed modified chitosan sorbent and capability of adsorption on cadmium ion Environmental Science \& Technology (China) 34:87-170

Zhang Z, Li M, Chen W, Zhu S, Liu N, Zhu L (2010) Immobilization of lead and cadmium from aqueous solution and contaminated sediment using nano-hydroxyapatite Environmental Pollution 158:514-519

Zhao K, Liu X, Xu J, Selim H (2010) Heavy metal contaminations in a soil-rice system: identification of spatial dependence in relation to soil properties of paddy fields Journal of Hazardous Materials 181:778787

Zibaei Z, Ghasemi-Fasaei R, Ronaghi A, Zarei M, Zeinali S (2020) Improvement of biochar capability in $\mathrm{Cr}$ immobilization via modification with chitosan and hematite and inoculation with Pseudomonas putida Communications in Soil Science and Plant Analysis 51:963-975

\section{Figures}

\section{Figure 1}

Effects of amendments (C:control; FSP:fish scale powder; CTN:chitin; CTS:chitosan) on shoot (a) and root (b) dry weight of rice grown on a polluted soil. In each part, mean values with the same letters are not significantly different according to Duncan's multiple range test $(p \leq 0.05)$. 
(a)
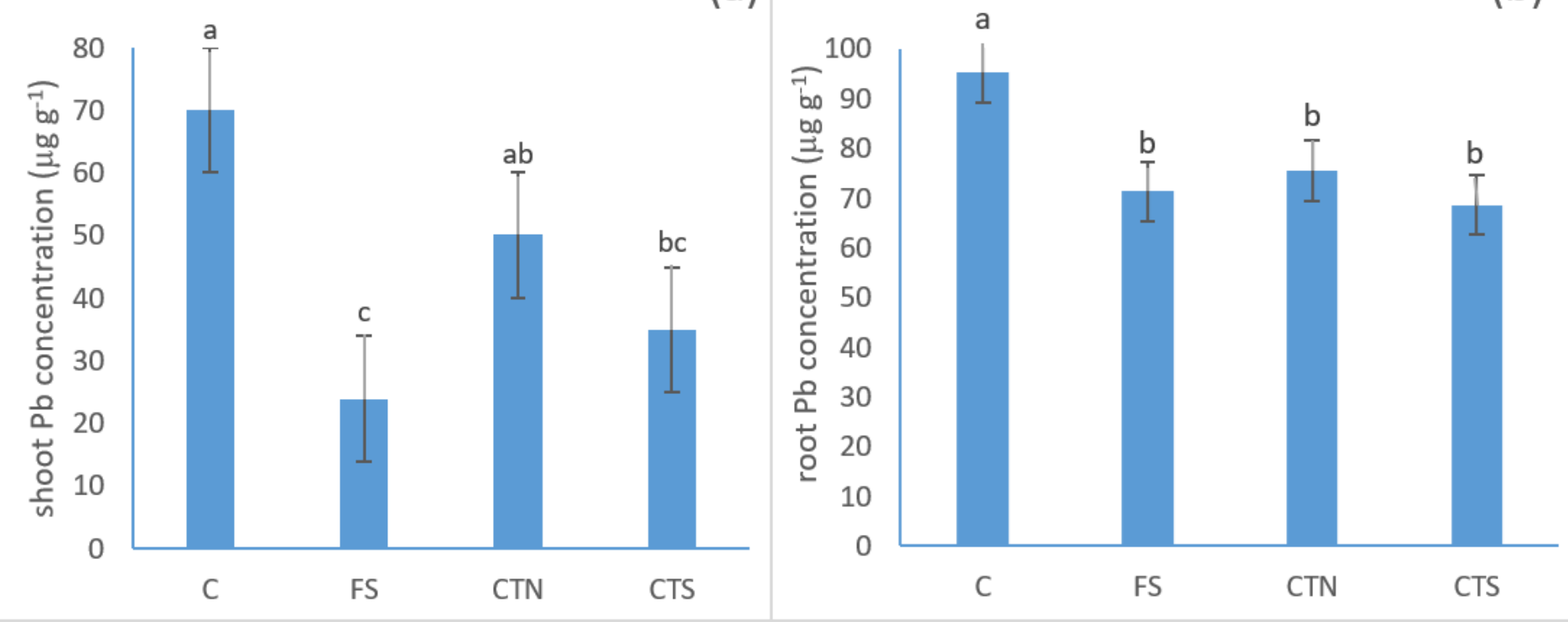

\section{Figure 2}

Effects of amendments (C:control; FSP:fish scale powder; CTN:chitin; CTS:chitosan) on Pb concentration in aerial parts (a) and roots(b) of rice grown on a polluted soil. In each part, mean values with the same letters are not significantly different according to Duncan's multiple range test $(p \leq 0.05)$.

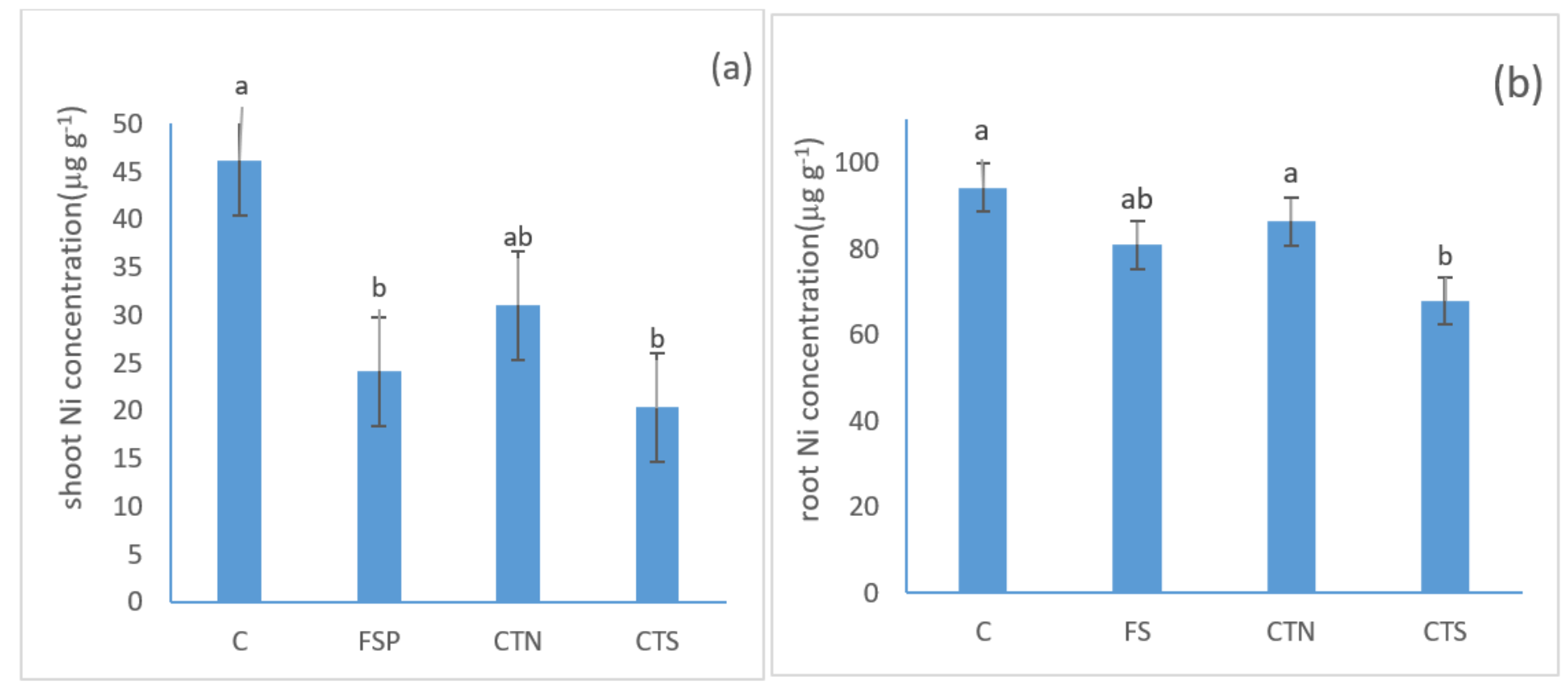

\section{Figure 3}

Effects of amendments (C:control; FSP:fish scale powder; CTN:chitin; CTS:chitosan) on Ni concentration in aerial parts (a) and roots(b) of rice grown on a polluted soil. In each part, mean values with the same 
letters are not significantly different according to Duncan's multiple range test $(p \leq 0.05)$.

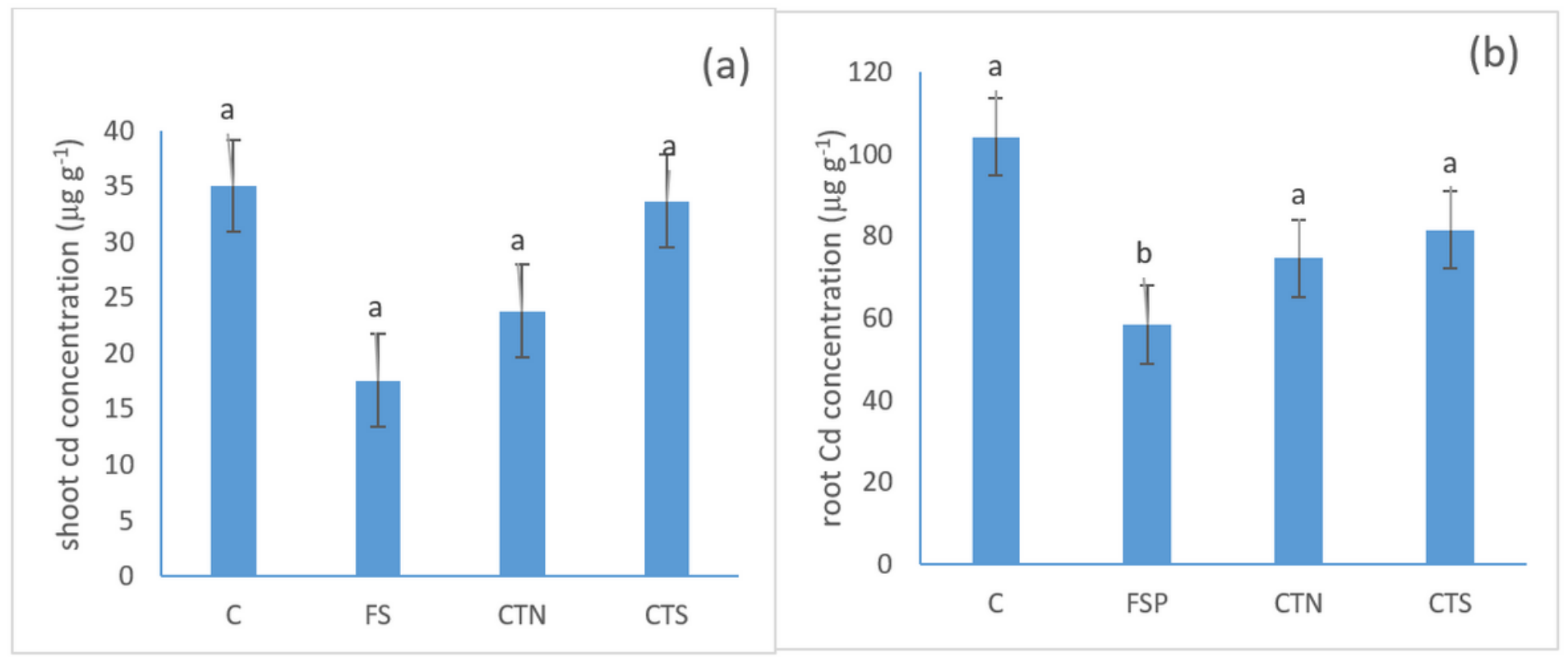

\section{Figure 4}

Effects of amendments (C:control; FSP:fish scale powder; CTN:chitin; CTS:chitosan) on Cd concentration in aerial parts (a) and roots(b) of rice grown on a polluted soil. In each part, mean values with the same letters are not significantly different according to Duncan's multiple range test $(p \leq 0.05)$.

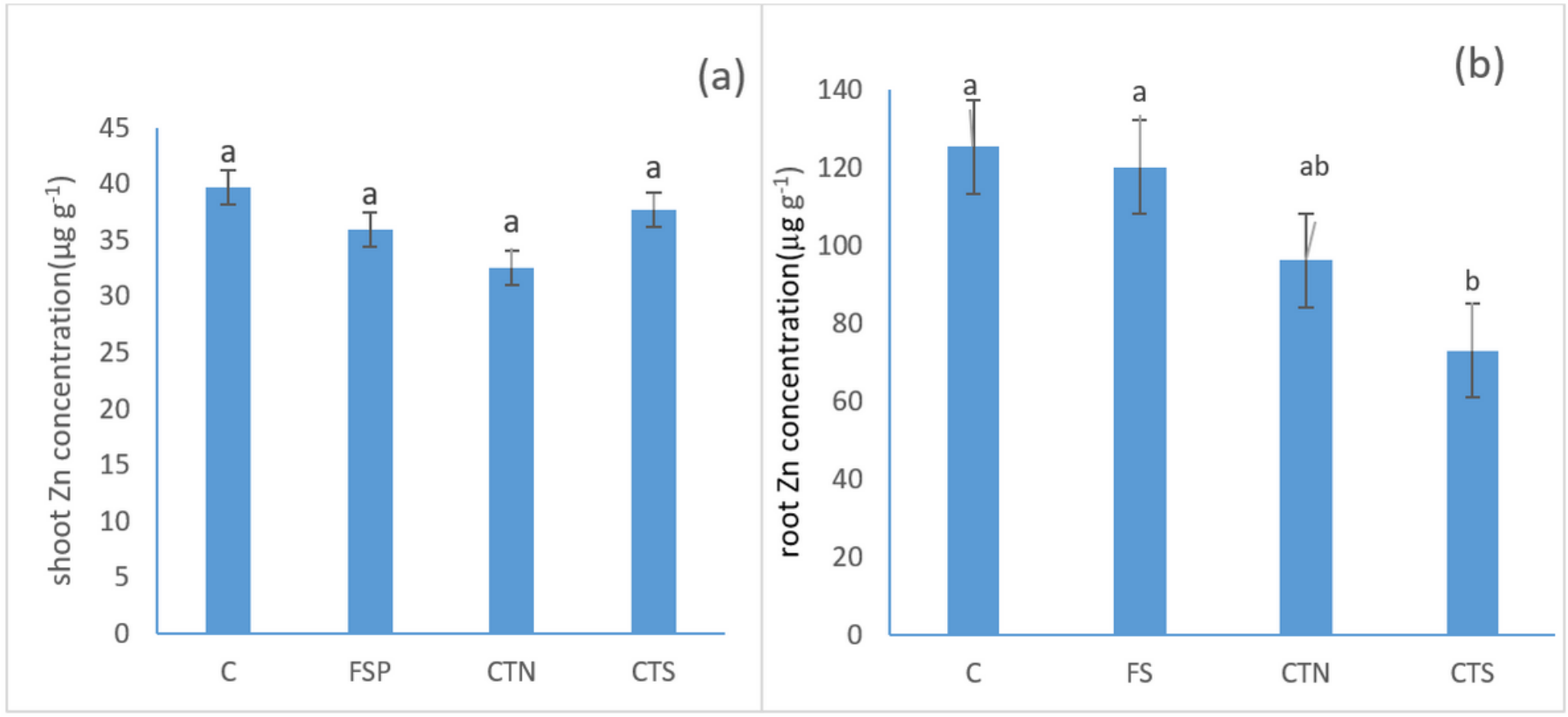




\section{Figure 5}

Effects of amendments (C:control; FSP:fish scale powder; CTN:chitin; CTS:chitosan) on Zn concentration in aerial parts (a) and roots(b) of rice grown on a polluted soil. In each part, mean values with the same letters are not significantly different according to Duncan's multiple range test $(p \leq 0.05)$. 